\title{
Tuberculosis prevalence among underfive children in household contact with negative acid fast bacilli adult pulmonary tuberculosis
}

\author{
Harry Iskandar, Heda Melinda D. Nataprawira, Herry Garna, Julistio T.B. Djais
}

\begin{abstract}
Background Risk of tuberculosis (TB) transmission is greatest if a child has household contact with positive acid fast bacilli (AFB) adult pulmonary TB. Risk of TB transmission from negative AFB adult pulmonary TB to underfive children is unknown.

Objective To find out the prevalence of TB infection and disease among underfive children in household contacts with negative AFB adult pulmonary TB.

Methods The study was performed at Balai Kesehatan Paru Masyarakat (BKPM) Bandung on underfive children who live in the same house with negative AFB adult pulmonary TB from February to July 2006. History taking, physical examination, anthropometric measurement, chest radiographs, and tuberculin skin test were performed to all study subjects. Subjects were then categorized as TB infection (positive tuberculin test only) or disease (defined based on Pulmonology Workgroup of Indonesian Paediatrics Council criteria, 2005).

Results Sixty one children ( 32 males and 29 females) had contact with 54 negative AFB adults pulmonary TB. Tuberculosis infection was found in six (10\%), while disease was found in $10(16 \%)$ children. The prevalence of TB infection was 10\% (95\% CI $2.3 ; 17.3)$ while prevalence of TB disease was $16 \%(95 \% \mathrm{CI}$ 7.1;24.7).

Conclusion Tuberculosis infection and disease prevalence is considerably high in household contact with negative EFB adult

pulmonary TB. [Paediatr Indones 2008;48:18-22].
\end{abstract}

Keywords: Tuberculosis, underfive children, contact,

negative acid fast bacilli
$\mathrm{T}$ uberculosis is still the one of leading causes of mortality throughout the world. WHO reports tuberculosis incidence rate approximately $140 / 100,000$ while the prevalence is $245 / 100,000$. Indonesia ranks the third position among the highest-incidence countries of TB with the incidence rate of approximately 245/ 100,000 while the prevalence is $675 / 100,000 .{ }^{1}$ The infection is almost exclusively transmitted through airborne from patients with pulmonary disease. The risk of transmission is highest from AFB positive adults pulmonary TB proportional to the bacillary density in respiratory secretions. ${ }^{2}$ Therefore, those who live in the same house are at higher risk than those with casual contacts. Many studies have shown that closeness and duration of contact with positive AFB adult pulmonary TB strongly associated with the prevalence of TB., ${ }^{1,5}$ Among household contacts, those who are very young is at increase risk of being infected by adult pulmonary TB. ${ }^{6-9}$

From The Department of Child Health, Medical School, Padjadjaran University, Hasan Sadikin Hospital, Bandung, Indonesia.

Reprint requests to: Harry Iskandar, MD, Department of Child Health, Medical School, Padjadjaran University, Hasan Sadikin Hospital. Jl. Pasteur No.38, Bandung, Indonesia. Tel. 62-22-2034426. Fax. 62-22-2035957. 
Unfortunately, prevalence of TB infection and disease among underfive children in household contact with negative AFB pulmonary $\mathrm{TB}$ in Indonesia is still unknown.

This study was carried out with the aim to find out the prevalence of TB infection and disease among underfive children in household contact with negative AFB adult pulmonary TB.

\section{Methods}

This study was conducted over a period of six months during February to July 2006 at Balai Kesehatan Paru Masyarakat (BKPM) Bandung, West Java, Indonesia. The population in this study was underfive children who had household contacts with negative AFB adult pulmonary TB.

Adults were diagnosed at BKPM Bandung as negative AFB pulmonary TB based on suggestive symptoms and signs, and chest X-ray, but had at least 2 out of 3 negative sputum specimens on Ziehl-Neelsen staining. ${ }^{2}$ Negative AFB adult pulmonary TB data were collected from the medical record. Written informed consent was obtained prior to enrollment.

Contacts were defined as children aged $4-<60$ months old who were living in the same house with the time of exposure at least 9 hours per day ${ }^{3}$ throughout three-month period or more. ${ }^{10}$ Children who had been previously treated for tuberculous infection, those who had household contact with positive AFB pulmonary TB or adult TB not living in the same house were excluded.

Information on household contacts was taken by interviewing their parents. The symptoms were collected according to Pulmonology Workgroup of Indonesian Paediatric Council criteria (2005) which contain 8 parameters including source of $\mathrm{TB}$, tuberculin skin test (TST), weight/nutritional status, fever, cough, lymph node enlargment, bone/joint swelling, and chest X-ray (Table 1). Scores of 0-3 were given to each parameter and diagnosis of TB disease were made if total of these scores $\geq 6 .{ }^{11}$

Anthropometric measurement was performed to assess nutritional status by measuring weight and height of a household contacts. Although it is not written in Pulmonology Workgroup of Indonesian Paediatrician Council TB Diagnostic criteria (2005), ${ }^{11}$ we used CDC Growth Chart (2000) ${ }^{12}$ as a standard reference for a nutritional status. The nutritional status were classified as weight for age (W/A) between $60-<80 \%$ or weight for height (W/H) $70-<90 \%$ group and W/A $<60 \%$ or W/H $<70 \%$ or clinically severe malnutrition group.

Table 1. Pulmonology Workgroup of Indonesian Paediatric Council Tuberculosis Diagnostic Criteria (2005)

\begin{tabular}{|c|c|c|c|c|}
\hline \multirow[t]{2}{*}{ Parameter } & \multicolumn{4}{|c|}{ Score } \\
\hline & 0 & 1 & 2 & 3 \\
\hline Source of TB & Unknown & $\begin{array}{l}\text { Family reports, } \\
\text { AFB (-) or unknown }\end{array}$ & $\begin{array}{l}\text { Cavities (+), } \\
\text { AFB unknown }\end{array}$ & AFB (+) \\
\hline $\begin{array}{l}\text { TST } \\
\mathrm{mm}\end{array}$ & Negative & & & $\begin{array}{l}\text { Positive }(=10 \mathrm{~mm} \text {, or }=5 \\
\text { in immuno-suppresion } \\
\text { patients) }\end{array}$ \\
\hline $\begin{array}{l}\text { Weight }(\mathrm{W}) / \\
\text { nutritional status }\end{array}$ & & $\mathrm{W} / \mathrm{H}<90 \%$ or W/A $<80 \%$ & $\begin{array}{l}\text { Clinically severe } \\
\text { malnutrition or W/H } \\
<70 \% \text { or } \mathrm{W} / \mathrm{A}<60 \%\end{array}$ & \\
\hline Fever & $\geq 2$ weeks & & & \\
\hline Cough & $\geq 3$ weeks & & & \\
\hline $\begin{array}{l}\text { Lymph node } \\
\text { enlargement: neck, } \\
\text { axilla, inguinal }\end{array}$ & 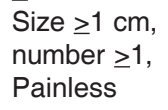 & & & \\
\hline Bone/joint swelling: & & Swelling $(+)$ & & \\
\hline CXR & Normal & $\begin{array}{l}\text { - Infiltrate } \\
\text { - Lymph node enlargement } \\
\text { - Segmental/ lobar consolidation } \\
\text { - Atelectasis }\end{array}$ & $\begin{array}{l}\text { - Calcification + infiltr } \\
\text { - Lymph node enlarg } \\
\text { infiltrate }\end{array}$ & nent + \\
\hline
\end{tabular}

Note:

If scrofuloderma is noted, the diagnosis is tuberculosis

Weight obtained in moment of admission

TB disease: total score $\geq 6$ 
All subjects underwent tuberculin skin test (TST) using the Mantoux method, a recommended technique for mass screening of M. tuberculosis infection. It was performed on the volar aspect of the forearm with $0.1 \mathrm{~mL}$ of 2 tuberculin unit (TU) of PPD RT 23.2,13 Contacts were asked to visit BKPM 48-72 hours later for evaluating the TST result. We used $\geq 10 \mathrm{~mm}$ as a cut-off value for mostly contacts and $\geq 5 \mathrm{~mm}$ as a cut-off value for severe malnutrition or immunosupressed children. The TST result was measured by the trained and experienced nurse.

Chest $x$-ray (CXR) was performed in two positions, i.e., anterior-posterior and lateral positions. An experienced pediatric radiologist expertised the CXR of the children.

Children were categorized as having TB infection if TST size $\geq 10 \mathrm{~mm}$ for most contacts and $\geq 5 \mathrm{~mm}$ for severe malnourished or immunosupressed children, while TB disease based on Pulmonology Workgroup of Indonesian Paediatrician Council criteria ${ }^{11}$ with a cut off point score $\geq 6$ (Table 1 ).

We included at least 61 children as study subjects based on assumption that the prevalence of AFB negative transmission was $0.21,{ }^{7}$ with a bound on error of 0.1 .

The study was initiated with the approval of the Institutional Ethics Committee of Medical School, University of Padjadjaran, Hasan Sadikin Hospital, Bandung, Indonesia and written informed consent of either parents.

\section{Results}

Over six-month period of the study, 54 out of 509 negative AFB adult pulmonary $\mathrm{TB}$ patients met the criteria. Those negative adults pulmonary $\mathrm{TB}$ met the criteria if they had a household contacts with underfive children at least 9 hours/day for at least 3 months, ${ }^{3,10}$ the patients and parents of underfive children agreed and signed the research consent. Fifty four negative AFB adult pulmonary TB had a mean age of 32 years (range 17-77 years) which most of them (39\%) had age ranged from 25 to 34 years. They comprised 38 (70\%) females and 16 (30\%) males.

Chest X-ray performed on all adult TB showed infiltrates and cavities in 48 (89\%) and 4 (7\%) respectively, while pleural effusion and milliary TB was found in 1 (2\%) each. Concerning the source of infection, $44(82 \%)$ were the child's parents $(60 \%$ mothers and $22 \%$ fathers).

Study population comprised 32 (52\%) males and $29(48 \%)$ females. The mean duration of contact was 20.34 hours per day. A total of 19 (31\%) children were W/A $60-<80 \%$ or W/H $70-<90 \%$. No children in this study had severe malnutrition. Eleven (18\%) had fever $\geq 2$ weeks and 14 (23\%) had lymph nodes enlargement. No children had cough $\geq 3$ weeks nor bone/joint swelling. Table 2 shows the characteristics of the subjects.

CXR abnormalities noted were infiltrate in 19 (31\%), calcification with infiltrate and lymph nodes enlargement with infitrate in five (8\%) each, lymph nodes enlargement in two (3\%), and atelectasis in one (2\%).

Tuberculin skin test were positive in 16 (26\%) of the children. Six out of 16 children had a total score less than 6 and they were diagnosed as TB infection. The prevalence of TB infection was 10\% [95\% CI 2.3;17.3].

Children with TB infection had a range of age of 5-36 $(\mathrm{X}=18.7)$ months. They comprised $4(67 \%)$ males and 2 (33\%) females. All of children had contact with their mother as an adult TB. The mean duration of contact was 23.17 hours per day. They all were well nourished. No children with TB infection had signs and symptoms of TB disease, nor they had

Table 2. Characteristics of underfive children

\begin{tabular}{lccc}
\hline \multicolumn{3}{c}{ Sex } \\
Characteristics & $\mathrm{n}(\%)$ & $\begin{array}{c}\text { Female } \\
\mathrm{n}(\%)\end{array}$ & $\begin{array}{c}\text { Total } \\
\mathrm{n}(\%\end{array}$ \\
\hline Anthropometry & & & \\
$\quad$ W/A 60-<80\% or W/H $70-<90 \%$ & $8(13)$ & $11(18)$ & $19(31)$ \\
$\quad$ W/A $<60 \%$ or W/H $<70 \%$ & 0 & 0 & 0 \\
Fever $\geq 2$ weeks & $6(10)$ & $5(8)$ & $11(18)$ \\
Cough $\geq 3$ weeks & 0 & 0 & 0 \\
Lymph node enlargement & $9(15)$ & $5(8)$ & $14(23)$ \\
Bone/joint swelling & 0 & 0 & 0 \\
Chest X-ray & & & \\
$\quad$ Normal & $14(23)$ & $15(25)$ & $29(48)$ \\
$\quad$ Abnormal & $18(30)$ & $14(23)$ & $32(53)$ \\
Tuberculin skin test & & & \\
$\quad$ Positive & $11(18)$ & $5(8)$ & $16(26)$ \\
$\quad$ Negative & $21(34)$ & $24(39)$ & $45(74)$ \\
Total score & & & \\
$\quad<6$ & $25(41)^{\star}$ & $26(43)^{\star *}$ & $51(84)$ \\
$\geq 6$ & $7(11)$ & $3(5)$ & $10(16)$ \\
\hline
\end{tabular}

* Four children had TST $(+)$

** Two children had TST (+) 
abnormalities on physical examination. Three (50\%) of them were noted to have infiltrate on CXR, while the other were normal. Table 3 shows characteristics of underfive children with TB infection.

Ten children had a total score $\geq 6$ and they were diagnosed as TB disease while 45 children had a total score $<6$ with TST $(-)$ and the remaining had a total score $<6$ with TST $(+)$. The prevalence of TB disease was $16.4 \%$ [95\%CI 7.1;25.7].

Children with TB disease had a range of age of 16-59 (mean=39.7) months and comprised of seven (70\%) males and three (30\%) females. They had contact with seven adult TB four of them were their mother, one father, one uncle, and one grandmother. The mean duration of contact was 20.1 hours per day.

Table 3. Characteristics of underfive children with TB infection

\begin{tabular}{lccc}
\hline & \multicolumn{2}{c}{ Sex } \\
Characteristics & $\begin{array}{c}\text { Male } \\
\mathrm{n}(\%)\end{array}$ & $\begin{array}{c}\text { Female } \\
\mathrm{n}(\%)\end{array}$ & $\begin{array}{c}\text { Total } \\
\mathrm{n}(\%)\end{array}$ \\
\hline Anthropometry & & & \\
$\quad$ W/A $60-<80 \%$ or W/H $70-<90 \%$ & 0 & 0 & 0 \\
$\quad$ W/A $<60 \%$ or W/H $<70 \%$ & 0 & 0 & 0 \\
Fever $\geq 2$ weeks & 0 & 0 & 0 \\
Cough $\geq 3$ weeks & 0 & 0 & 0 \\
Lymph node enlargement & 0 & 0 & 0 \\
Bone/joint swelling & 0 & 0 & 0 \\
Chest X-ray & & & \\
$\quad$ Normal & $3(50)$ & 0 & $3(50)$ \\
$\quad$ Infiltrate & $1(17)$ & $2(33)$ & $3(50)$ \\
$\quad$ Lymph node enlargement & 0 & 0 & 0 \\
$\quad$ Segmental/lobular consolidation & 0 & 0 & 0 \\
$\quad$ Atelectasis & 0 & 0 & 0 \\
$\quad$ Calcification + infiltrate & 0 & 0 & 0 \\
Lymph node enlargement + infiltrate & 0 & 0 & \\
\hline
\end{tabular}

Table 4. Characteristics of underfive children with TB disease

\begin{tabular}{lccc}
\hline & \multicolumn{3}{c}{ Sex } \\
Characteristics & $\begin{array}{c}\text { Male } \\
\mathrm{n}(\%)\end{array}$ & $\begin{array}{c}\text { Female } \\
\mathrm{n}(\%)\end{array}$ & $\begin{array}{c}\text { Total } \\
\mathrm{n}(\%\end{array}$ \\
\hline Anthropometry & & & \\
$\quad$ W/A $60-<80 \%$ or W/H $70-<90 \%$ & 3 & 2 & 5 \\
$\quad$ W/A $<60 \%$ or W/H $<70 \%$ & 0 & 0 & 0 \\
Fever $\geq 2$ weeks & 1 & 0 & 1 \\
Cough $\geq 3$ weeks & 0 & 0 & 0 \\
Lymph node enlargement & 3 & 1 & 4 \\
Bone/joint swelling & 0 & 0 & 0 \\
Chest X-ray & & & \\
$\quad$ Normal & 1 & 0 & 1 \\
Infiltrate & 2 & 2 & 4 \\
$\quad$ Lymph node enlargement & 1 & 0 & 1 \\
$\quad$ Segmental/lobular consolidation & 0 & 0 & 0 \\
$\quad$ Atelectasis & 0 & 0 & 0 \\
$\quad$ Calcification + infiltrate & 1 & 0 & 1 \\
Lymph node enlargement + infiltrate & 2 & 1 & 3 \\
\hline
\end{tabular}

Five were mild malnutrition (W/A $60-<80 \%$ or W/H 70-<90\%), while the other were well nourished. Fever $\geq 2$ weeks was present in one and lymph nodes enlargement in four. No children had cough $\geq 3$ weeks nor bone/joint swelling.

CXR abnormalities on TB disease were infiltrate in four lymph nodes enlargement with infitrate three, calcification with infiltrate one, lymph nodes enlargement one, while one was normal. Table 4 shows characteristics of underfive children with TB disease.

\section{Discussion}

From WHO data in year of 2003 for demographic characteristics in most countries in SEAR region, we found that group of age 25-34 years have the highest incidence of TB. ${ }^{1}$

Similar to what the study conducted by Caldeira et $\mathrm{al}^{14}$, parents were the most common source of infection in children with a household contacts. Most of contacts were their mothers (60\%), which expected because most mothers stayed at home, close to their children, and had the longest contacts duration.

The prevalence of TB infection in this study was less than that of the study conducted by Singh et al ${ }^{7}$ and Nakaoka et al. ${ }^{15}$ Unlike the previous study, we differentiated TB infection from disease. If we performed a study to find prevalence of TB infection only based on tuberculin skin test, we found greater prevalence (26\%; $95 \%$ CI 15.2-37.2) than that of the study by Singh et al and Nakaoka et al ${ }^{15}$.

This condition maybe related to our limitation in this study that we couldn't exclude the possibility of positive AFB due to limitation of microscopic examination with Ziehl-Neelsen smear sensitivity. ${ }^{16,17}$ Thus, there was posibility of false negative sputum microscopically. Another possibility is that we also couldn't exclude the possibility of AFB positive adult TB living in the same house and the possibility of transmission from adult TB living not in the same house.

The other limitation in this study is that the diagnostic criteria is still on progress and the absence of true gold standard for TB diagnosis in children.

The prevalence of TB disease was $16 \%$, while prevalence of TB infection was $10 \%$. This prevalence 
Harry Iskandar et al: Tuberculosis prevalence in negative acid fast bacilli contacts

was considerably high in this study population. It needs an analytic study to test risk factors of infected and diseased TB, and minimize the limitation in this study. We suggest that every children in household contact with negative AFB adult pulmonary TB must have a screening for possibility of TB infection or disease.

We conclude that tuberculosis infection and disease prevalence is considerably high in household contacts with negative acid bacilli adult pulmonary tuberculosis in this study.

\section{References}

1. WHO. Global tuberculosis control: surveillance, planning, financing - WHO report 2005. Geneva, 2005. WHO/HTM/ TB/2005.349.

2. Ait-Khaled N, Enarson DA. Tuberculosis-a manual for medical student, Geneva, 2003. WHO/CDS/TB/99.272.

3. Lutong L, Bei Z. Association of prevalence of tuberculin reactions with closeness of contact among household contacts of new smear-positive pulmonary tuberculosis patients. Int J Tuberc Lung Dis 2000;4:275-7.

4. Reichler MR, Reves R, Bur S, Thompson V, Mangura BT, Ford J, et al. Evaluation of investigations conducted to detect and prevent transmission of tuberculosis. JAMA 2002; 287:991-5.

5. Espinal MA, Raviglione MC. Global epidemiology of tuberculosis. In: Madkour MM, editor. Tuberculosis. Berlin: Springer-Verlag; 2004. p. 33-43.

6. Beyers N, Gie RP, Schaaf HS, van Zyl S, Talent JM, Nel ED, et al. A prospective evaluation of children under the age of 5 years living in the same household as adults with recently diagnosed pulmonary tuberculosis. Int J Tuberc Lung Dis 1997;1:38-43.

7. Singh M, Mynak ML, Kumar L, Mathew JL, Jindal SK. Prevalence and risk factors for transmission of infection among children in household contact with adults having pulmonary tuberculosis. Arch Dis Child 2005;90:624-8.
8. Mtombeni S, Mahomva A, Siziva S, Sanyika C, Doolabh R, Nathoo KJ. A clinical evaluation of children under the age of five years who are household contacts of adults with sputum positive tuberculosis in Harare, Zimbabwe. Central African J Med 2002;48:28-32.

9. Shah NS, Harrington T, Huber M, Wellnitz C, Fridrych S, Laserson $\mathrm{K}$, et al. Increased reported cases of tuberculosis among children younger than 5 years of age, Maricopa County, Arizona, 2002-2003. Pediatr Infect Dis J 2006; 25:151-5.

10. Rathi SK, Akhtar S, Rahbar MH, Azam SI. Prevalence and risk factors associated with tuberculin skin test positivity among household contacts of smear-positive pulmonary tuberculosis cases in Umerkot, Pakistan. Int J Tuberc Lung Dis 2002;6:851-7.

11. UKK Pulmonologi PP IDAI. Pedoman nasional tuberkulosis anak. Jakarta: IDAI; 2005.

12. Center for Disease Control and Prevention. 2000 CDC growth chart. cited 2006 February $9^{\text {th }}$. Available from: http:/ /www.cdc.gov/nchs/data/nhanes/ growthcharts/set2clinical/ set2b\&w.pdf.

13. Statens Serum Institut - Product - Tuberculin 2002. cited 2006 February $6^{\text {th }}$. Available from: http://www.ssi.dk/ sw4248.asp.

14. Caldeira ZMR, Sant'Anna CC, Aide MA. Tuberculosis contact tracing among children and adolescents, Brazil. Rev Saude Publica 2004;8:1-6.

15. Nakaoka H, Lawson L, Squire B, Coulter B, Ravn P, Brock I, et al. Risk for tuberculosis among children. Emerg Infect Dis 2006;12:1383-8.

16. Laserson KF, Yen NTN, Thornton CG, Mai VTC, Jones W, An DQ, et al. Improved sensitivity of sputum smear microscopy afterprocessing specimens with C18-Carboxypropylbetaine to detect acid-fast bacilli: a study of United State-bound immigrants from Vietnam. J Clin Microbiol 2005;43:3460-2.

17. Scott CP, Filho LDA, Mello FCQ, Thornton CG, Bishai WR, Fonseca LS, et al. Comparison of C18-Carboxypropylbetaine and standard $\mathrm{N}$-acetyl-L-Cysteine- $\mathrm{NaOH}$ processing of respiratory specimens for increasing tuberculosis smear sensitivity in Brazil. J Clin Microbiol 2002;40:3219-22. 